\title{
INFLUENCE OF SHIITAKE MUSHROOM Lentinula edodes ON REPRODUCTION OF Drosophila melanogaster
}

\author{
Elīna Svilpe and Natalja Matjuškova \\ University of Latvia, Faculty of Biology, Kronvalda bulv. 4, Rīga, LV-1586, LATVIA \\ E-mail: natalja.matjuskova@lu.Iv
}

Communicated by Indrikis Muižnieks

\begin{abstract}
Shiitake mushroom Lentinula edodes is an edible basidiomycete cultivated worldwide, with high nutritious value and diverse biological activity. There has been an increase in its use as food supplement. Influence of shiitake mushroom extract on the reproductive function and development in an object fruit fly Drosophila melanogaster is described in this research. Fruit flies were maintained on banana medium with or without supplementation of shiitake mushroom 's extract, standardized per amount of crude polysaccharides. Shiitake extract supplement, $0.030 \%$ and $0.015 \%$ crude polysaccharides per volume, induced a statistically significant increase in total number of pupae and flies, and promoted pupae viability. Adult drosophilae males, which received shiitake extract supplement for seven days, had a statistically significant reduction in copulation latency, while thirty day exposure to extract promoted a statistically higher rate of mated flies. Females showed an increase in number of mated flies and reduction in copulation latency post seven day feeding period and had no significant effect on mating ability and fertility post thirty days. Further studies are planned to identify the biologically active components of shiitake mushroom hot water extract and to characterize their effects on reproductive function.
\end{abstract}

Key words: shiitake mushroom, water extract, fruit fly, reproduction.

\section{INTRODUCTION}

Shiitake Lentinula edodes (Berk.) Pegler is an edible mushroom cultivated worldwide with medicinal properties (Mizuno, 1995; Chang et al., 1999; Hobbs, 2000).

In traditional Orient medicine it is used to promote good health and vitality and to increase the body's adaptive capabilities (Mizuno, 1995; Chang et al., 1999; Yap and Ng, 2005). It also has anti-inflammatory, antitumor, antibacterial, antiviral, blood pressure and cholesterol level regulating, anti-diabetic, hepatoprotective and sexual function improving applications (Chang et al., 1999; Wasser and Weis, 1999; Stamets, 2002).

Some shiitake components have been studied in details and their pharmacological activities have been shown. Most studies of active substances, incl. polysaccharides, are performed to investigate immune system modulating, antioxidative, antimutagenic and cholesterol reducing effects in various biological systems in vivo and in vitro (Chihara et al., 1970; Hobbs, 2000; Yap and Ng, 2005; Lee et al., 2009 b). In comparison with other effects, there is little information of the influence of shiitake on animal reproduction and development (Cozens et al., 1981a; Cozens et al., 1981b; Cozens et al., 1981c; Zorenko et al., 2003).

In studies on biological active substances of shiitake as models standard laboratory animals, such as mice, rats, and rabbits have been used (Chihara et al., 1970; Cozens et al., 1981a; 1981b). The biological activity of shiitake was shown in a Social vole model (Matjuskova et al., 2001). Fruit fly Drosophila melanogaster is one of the main organisms used for study in various fields of biology, including researches on biological substances. It is used for screening potential medicinal properties of chemicals (Tickoo and Russell, 2002) and botanicals (Li et al., 1993; Taira et al., 2005; Jafari et al., 2007; Bahadorani and Hilliker, 2008; Zhao et al., 2008; Jafari et al., 2008; Матюшкова и др., 2010), as well as for evaluating toxicity of various compounds (Goldstein and Babich, 1989; Affleck and Walker, 2008). Evolutionary conservation has been identified between fly and human genomes, and there are similarities in sex determination, gametogenesis, embriogenesis, aging process, host defense and other processes (Tickoo and Russell, 2002; Helfand and Rogina, 2003; Zhang et al., 2004; Haag and Doty, 2005; Mutova and Cooley, 2005; Lemaitre and Hoffmann, 2007).

We suggest that fruit fly is a well suited model organism for studying the spectra of biological activity of shiitake mushroom. There are several reasons for using drosophila in laboratory studies, such as, well described biology and protocols, short life cycle, low costs, relative easy maintenance and biological similarities which they share with higher animals. In Latvian legislation there are no regulations on in- 
vertebrate, including insects, use in laboratory procedures (Anonīms, 2010).

The present study aimed to evaluate the effects of shiitake mushroom hot water extract on D. melanogaster pupa and fly development and on reproductive function, including fly fertility and mating ability in terms of copulation latency, duration of copulation, remating and number of mating flies.

\section{MATERIALS AND METHODS}

Preparation of aqueous extract of shiitake mushroom. Fresh fruiting bodies (200 g) of L. edodes strain DSM3565 (German Collection of Microorganisms and Cell Cultures) were homogenised and extracted with distilled boiling water (1 L) for $15 \mathrm{~h}$ at $80{ }^{\circ} \mathrm{C}$. Supernatant was obtained by centrifugation; insoluble matter was removed. The amount of crude polysaccharides in hot water extract was determined by ethanol precipitation (Chihara et al., 1970). Approximate crude polysaccharide content in shiitake fruiting body extract was 1.7 gram per litre. The extract was pasteurised, lyophilised and stored at $4{ }^{\circ} \mathrm{C}$ until use in current experiments.

Rearing of flies. The line of Normal (wild type) $D$. melnogaster used for study was obtained from the Institute of Biology, University of Latvia. To ensure genetic homogeneity of the drosophila population an inbreeding procedure had been employed. All flies were maintained on banana medium (Demerc and Kaufman, 1996) in standard $50 \mathrm{ml}$ plastics vials at $23 \pm 1{ }^{\circ} \mathrm{C}, 12: 12 \mathrm{~h}$ light: dark cycle and $50 \%$ relative humidity. Before use, a suspension of dry baker's yeast $(0.5 \mathrm{mg}$ per $25 \mathrm{ml})$ was added on the medium surface. Virgins were collected by diethyl ether separating males and females within $12 \mathrm{~h}$ post eclosion. Adult flies were maintained in batches of 20 flies per vial.

A water solution (E) of shiitake lyophilized extract was added to banana medium or to yeast suspension maintaining a standard crude polysaccharides content. There were three treatment groups: control group (Control) — flies maintained without extract, and two groups exposed to shiitake extract supplement (E 0.015\%; E 0.030\%) - 0.015\%, $0.030 \%$ polysaccharides per volume of medium or baker's yeast suspension, respectively.

Development test. The influence of shiitake on development was estimated by pupa and fly yield as well as by pupae viability. One male and two females were transferred to vials containing banana medium with or without shiitake extract supplement. Flies were allowed to mate and they laid eggs for seven days, then they were discarded from vials. Larvae were allowed to feed, develop and undergo a metamorphosis. First-generation pupae and flies were counted for seven successive days after their emergence (Goldstein and Babich, 1989; Pendleton et al., 2000). Pupa to imago viability was determined as percentage of viable flies produced by pupae (Tantawy and El-Helw, 1970).
Replication was 6 to 11 vials per group and the experiment was performed three times.

A mating ability test. Mating ability test was performed for flies that received shiitake supplement as imago. Five days old virgin females and males were fed separately with shiitake supplement added to yeast suspension for seven and thirty day periods. Flies were moved to fresh medium every seven days. Approximately twenty-four hours before the test flies were set-up singly on medium without supplement. Ten-days-old virgin mates from a Normal line population (two females or males) were exposed to experimental group flies in mating vials.

Mating behaviour patterns were recorded during a 120minute observation period. Copulation latency (mating speed), duration of copulation, male remating time and duration of second copulation as well as number of mating flies were determined (Mac Bean and Parson, 1967; Singh and Singh, 2000). Twenty mating vials were set up for each group.

Fertility test. After the mating ability test, flies were allowed to mate and lay eggs for two days and then discarded. Fertility was determined as $\mathrm{F}_{1}$ fly number per vial (Tantawy and El-Helw, 1970). Drosophilae development from egg to adult fly in laboratory conditions lasted approximately twelve days (data not shown). Therefore, offspring number was determined at the eighteenth day post laying to ensure that only for F1 progeny were counted. Offspring number was determined in control and shiitake supplement fed groups after a 30-day exposure. Twenty pairs were examined for each group.

Statistical analysis. Data were processed by Microsoft Office Excel 2003. For development test, fertility test and for mating behavior patterns, data on copulation latency, remating time, duration of first and second copulation, are presented as mean \pm standard error of mean (SE) and standard deviation (SD); in the mating ability test, the number of mating flies are expressed as percentage of total fly number per group. Statistical analysis was performed using SPSS 18 for Windows. Significant differences between experimental groups and control were determined by one-way analysis of variance (Least Significant Difference test, LSD) and the Chi-square test.

\section{RESULTS}

Effect of shiitake hot water extract on fly yield and viability. Shiitake extract supplement caused an increase in pupae and fly yield and pupae viability. The group receiving extract in banana medium $(0.030 \%$ polysaccharide per volume) had a statistically significantly higher mean number of pupae and flies, and pupae viability than the control group - 1.2, 1.5 and 1.3 times, respectively. In extract supplement $(0.015 \%$ polysaccharide per volume) the differences with the control in fly yield and pupa to imago viability were not significant (Table 1). 
YIELD AND VIABILITY OF D. melanogaster EXPOSED TO SHIITAKE SUPPLEMENT

\begin{tabular}{l|c|c|c|c|r|r}
\hline \multirow{2}{*}{ Group } & \multirow{2}{*}{$\mathrm{N}$} & \multicolumn{2}{|c|}{ Number of pupae } & \multicolumn{2}{c|}{ Number of flies } & \multicolumn{2}{c}{ Pupae viability \% } \\
\cline { 3 - 7 } & & mean \pm SEM & SD & mean \pm SEM & SD & mean \pm SEM \\
\hline Control & 28 & $46.54 \pm 3.48$ & 18.42 & $27.04 \pm 3.83$ & 20.25 & 22.68 \\
E $0.015 \%$ & 27 & $56.59 \pm 3.65^{*}$ & 18.95 & $36.19 \pm 3.99$ & 20.73 & $60.80 \pm 3.70$ \\
E $0.030 \%$ & 27 & $56.70 \pm 3.12^{*}$ & 16.23 & $39.44 \pm 4.14 *$ & 21.50 & $66.05 \pm 3.43 *$
\end{tabular}

Control - no supplement; E $0.015 \%$, E $0.030 \%$ - extract supplement in respect to its crude polysaccharides content $(0.015 \%, 0.030 \%$ - crude polysaccharides per volume of banana medium). SEM, standard error of mean, SD, standard deviation, N, number of vials. The significance of the difference between means was determinate by one-way analysis of variance (LSD test) $(* P<0.05)$.

Effect of shiitake hot water extract on fly mating ability. Fly mating ability increased with a shiitake extract supplement diet (Table 2, Fig. 1 and Fig. 2). After seven-day exposure to shiitake extract supplement in both concentrations $0.015 \%$ and $0.030 \%$ of crude polysaccharides respectively), the number of mated females significantly increased in comparison to the control (Table 2). Males showed a statistically significant effect on $0.015 \%$ diet after thirty days of feeding (Table 2).

Shiitake extract supplement received for seven days, in comparison to control, reduced copulation latency in males (Fig. 1 A) and females (Fig. 2), and induced a decrease of male remating time (Fig. 1 B). An effect of a post seven-day

Table 2

MATING ABILITY OF D. melanogaster MALES AND FEMALES EXPOSED TO SHIITAKE EXTRACT SUPPLEMENT FOR DIFFERENT TIME PERIODS

\begin{tabular}{|c|c|c|c|}
\hline $\begin{array}{c}\text { Exposure } \\
\text { time }\end{array}$ & Group & $\begin{array}{c}\text { Percentage of } \\
\text { mated flies }\end{array}$ & $\begin{array}{l}\text { Percentage of } \\
\text { remated flies }\end{array}$ \\
\hline \multicolumn{4}{|l|}{7 days } \\
\hline \multicolumn{4}{|c|}{ Males (ठ중) } \\
\hline & Control & 100.0 & 68.8 \\
\hline & E $0.015 \%$ & 93.8 & 62.5 \\
\hline & E $0.030 \%$ & 93.8 & 62.5 \\
\hline & \multicolumn{3}{|l|}{ Females $(\hat{\partial} \hat{\partial} \mathbf{x}+9)$} \\
\hline & Control & 29.4 & nd \\
\hline & E $0.015 \%$ & $70.6^{* *}$ & nd \\
\hline & E $0.030 \%$ & $88.9 * *$ & nd \\
\hline \multicolumn{4}{|l|}{30 days } \\
\hline \multicolumn{4}{|c|}{ 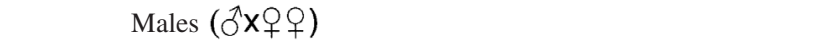 } \\
\hline & Control & 20.0 & 5.0 \\
\hline & E $0.015 \%$ & $50.0^{* *}$ & 10.0 \\
\hline & E $0.03 \%$ & 35.0 & 0.0 \\
\hline \multicolumn{4}{|c|}{ Females $(\hat{\jmath} \mathbf{x}+\varphi)$} \\
\hline & Control & 45.0 & nd \\
\hline & E $0.015 \%$ & 60.0 & nd \\
\hline & E $0.030 \%$ & 50.0 & nd \\
\hline
\end{tabular}

Control - no supplement; E $0.015 \%$, E $0.030 \%$ - extract supplement in respect to its crude polysaccharides content $(0.015 \%, 0.030 \%$ - crude polysaccharides per volume of baker' yeast suspension). Per each group were performed twenty vials. Remating was not determined for female groups (nd). The significance of the difference between experimental groups and control was determinate by Chi-square test $(* * P<0.01)$. feeding period was statistically significant only for copulation latency in males in group E $0.030 \%$ and females in group E $0.015 \%$. The supplement had no visible effect on duration of copulation (Fig. 1 A, B, Fig. 2). There was no statistically significant difference in copulation latency, remating time and duration of copulations between shiitake extract supplement fed groups and the control after thirty days of feeding (data not shown).

Effect of shiitake hot water extract on fly fertility. There was no statistically significant increase in mean number of progeny per fertile males fed with shiitake extract supplement for thirty days, and shiitake showed no remarkable effect also on female fertility (Table 3).

\section{DISCUSSION}

The present study demonstrates that shiitake mushroom hot water extract has an effect on $D$. melanogaster reproduction and development. There was an increase in pupae, fly yield and pupa to imago viability when larvae passed through metamorphosis on shiitake extract supplemented medium. Drosophilae exposure to a shiitake supplement at the imago stage improved mating ability and fertility. The effects depended on supplement concentration, exposure time and, in

Table 3

FERTILITY OF D. melanogaster MALES AND FEMALES AFTER THIRTY DAY EXPOSURE TO SHITTAKE EXTRACT SUPPLEMENT

\begin{tabular}{|c|c|c|c|c|}
\hline \multirow[t]{2}{*}{ Group } & \multirow[t]{2}{*}{$\mathrm{N}$} & \multirow{2}{*}{$\begin{array}{l}\text { Number of } \\
\text { fertile flies }\end{array}$} & \multicolumn{2}{|c|}{ Number of offspring flies } \\
\hline & & & $(\operatorname{mean} \pm \mathrm{SEM})$ & SD \\
\hline \multicolumn{5}{|c|}{ Males ( $\delta \mathbf{x}+q)$} \\
\hline Control & 19 & 16 & $46.19 \pm 6.56$ & 26.25 \\
\hline E $0.015 \%$ & 20 & 16 & $57.44 \pm 5.26$ & 21.02 \\
\hline E $0.03 \%$ & 20 & 18 & $54.06 \pm 5.91$ & 25.08 \\
\hline \multicolumn{5}{|c|}{ Females $\left(\hat{\partial} \widehat{o}^{\lambda} \mathbf{x}\right)$} \\
\hline Control & 19 & 13 & $27.92 \pm 4.10$ & 14.79 \\
\hline E $0.015 \%$ & 20 & 16 & $24.29 \pm 3.58$ & 14.33 \\
\hline E $0.030 \%$ & 19 & 15 & $23.60 \pm 3.07$ & 11.90 \\
\hline
\end{tabular}

Control - no supplement; E $0.015 \%$, E $0.030 \%$ - extract supplement in respect to its crude polysaccharides content $(0.015 \%, 0.030 \%$ - crude polysaccharides per volume of baker' yeast suspension). SEM, standard error of mean, SD, standard deviation, N, number of fly couples. The significance of the difference between means was determinate by one-way analysis of variance (LSD test). 

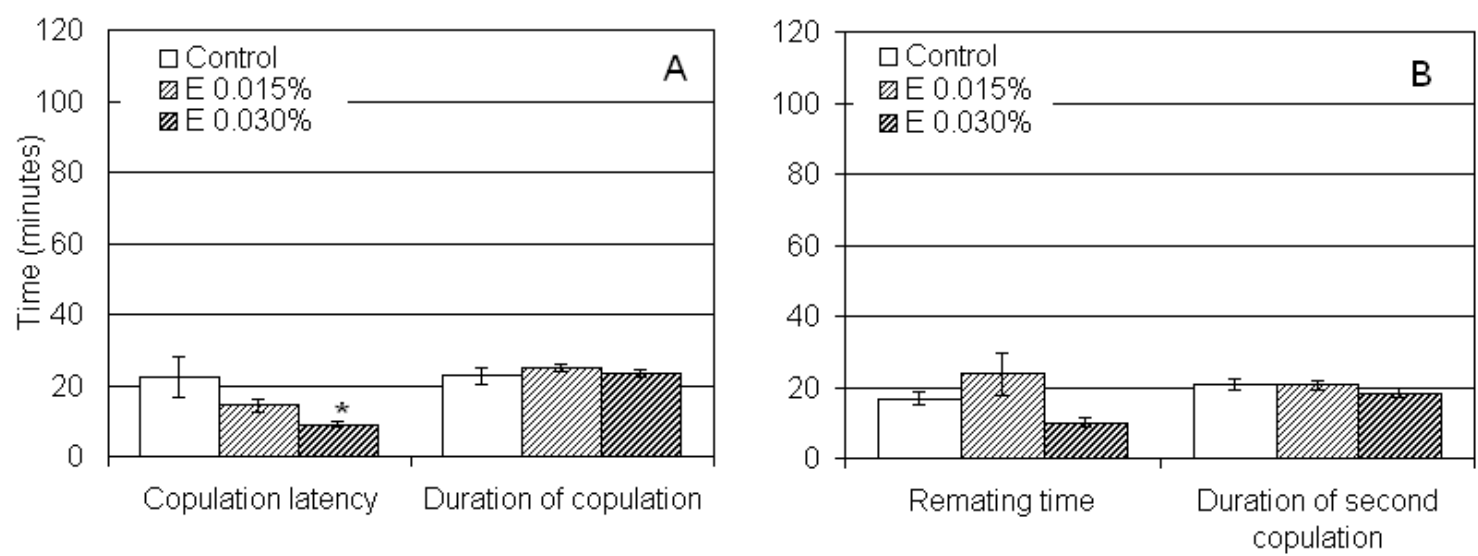

Fig. 1. Mating (A) and remating (B) ability of D. melanogaster males exposed to shiitake extract supplement for seven days. Control - no supplement; E $0.015 \%$, E $0.030 \%$ - extract supplement in respect to its crude polysaccharides content $(0.015 \%, 0.030 \%$ - crude polysaccharides per volume of baker' yeast suspension). Data is expressed as mean number \pm standard error of mean of twenty vials. The significance of the difference between means was determinate by one-way analysis of variance (LSD test) $(* P<0.05)$

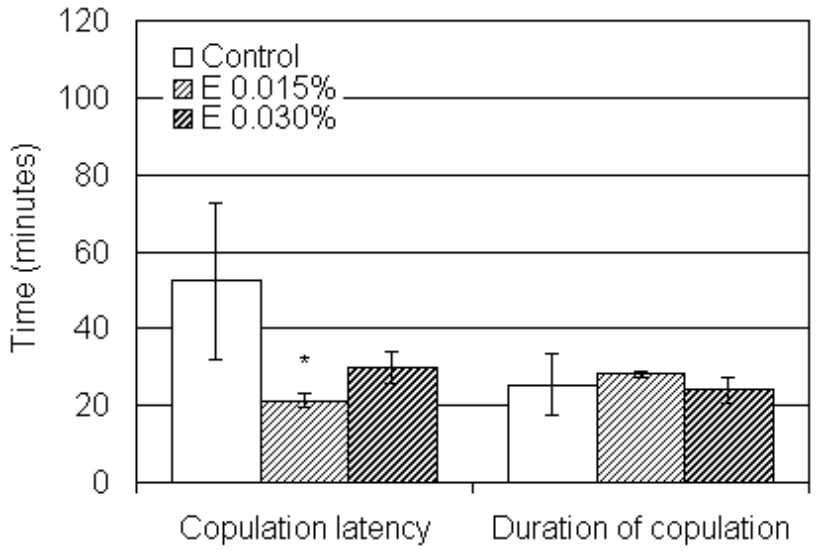

Fig. 2. Mating ability of D. melanogaster females exposed to shiitake extract supplement for seven days. Control - no supplement; E $0.015 \%$, E $0.030 \%$ - extract supplement in respect to its crude polysaccharides content $(0.015 \%, 0.030 \%$ - crude polysaccharides per volume of baker' yeast suspension). Data is expressed as mean number \pm standard error of mean of twenty vials. The significance of the difference between means was determinate by one-way analysis of variance (LSD test) $(* P<0.05)$.

some cases, on drosophilae sex. Increase in fly yields and pupae viability was more remarkable at higher shiitake extract concentration, $0.030 \%$ polysaccharide per volume of medium. Mating ability and fertility responses to supplement mostly were similar in both concentrations. The differences in responses might be explained by a difference in supplement intake, at larval and imago stages, respectively. Fly mating ability and fertility declines with age (Grotewiel et al., 2005). Our results differed in some respects with theory on female mating ability, as in the control group it was low at young age and did not decline with age. We used the fertility test only post thirty-day exposure period, as we supposed that differences between control and supplement fed groups would differ more remarkable in old age drosophilae than in young flies.

Our results are similar to those using other model organisms, such as Social vole Microtus socialis (Zorenko et al., 2003) and rats (Matjuskova et al., unpublished data). There were improvements in Social vole fertility and offspring ontogenesis and rat male mating ability when animals were fed with shiitake hot water extracts (Zorenko et al., 2003; Matjuskova et al., unpublished data).

Shiitake mushroom is known to affect sexual function (Chang et al., 1999; Wasser and Weis, 1999; Stamets, 2002) and this has been suggested also for mushrooms Cordyceps sinensis (Stamets, 2002) and Ganoderma lucidum (Wasser and Weis, 1999). In literature there are little data on botanical, including mushroom, substance effects on D. melanogaster mating ability; one of the few researches in this area is about Coriolus versicolor (Li et al., 1993). Li et al., (1993) observed that fruit fly mating frequency, progeny number and female mean life span were increased by exposure to $C$. versicolor polysaccharides.

The biological activity of zinc, eritadenine and immune system modulating polysaccharides, especially lentinan ( $\beta$-1,3-D glucan), have been suggested as substances that might explain the shiitake effect on sexual function (Flynn, 1991; Chang et al., 1999). Hot water extraction is one of the main methods used for obtaining material rich in high molecular weight polysaccharides from different natural sources, including shiitake mushroom (Miles and Chang, 1997; Zhang et al., 2007; Lee et al., 2009b). With this procedure it is possible to obtain different types of biologically active polysaccharides, such as non-protein bound $\beta$-glucans, including lentinan, heteropolysaccharides and protein-bound polysaccharides (Chihara et al., 1970; Zhang, et al., 2007; Lee et al., 2009a). Mushroom polysaccharides are well known as immunomodulators (Smith et al., 2002; Yap and Ng, 2005, Lee et al., 2009b). Host defense triggering by $\beta$-glucans has been described in vertebrates and in invertebrates (Vetvicka, Sima, 2004; Novack, Vetvicka, 2009). In organisms, physiological system activities are integrated. The immune system interacts with many processes in organisms, including reproductive function. This relationship also has been noted in invertebrates (Lutton and Callard, 2006). It is known that D. melanogaster and vertebrates, including human, share similarities in intracellular 
signaling pathways, humoral and cellular responses of innate immunity (Lemaitre and Hoffmann, 2007).

In conclusion, it could be suggested that there are some general mechanisms by which shiitake influences animal reproductive function and that one of the substances mediating this effect might be polysaccharides. The studies are being continued to determine shiitake polysaccharide effects on fruit fly life span and fertility, in terms of gamete production and it viability.

\section{ACKNOWLEDGEMENTS}

The work has been supported by European Social Fund project "Support for Doctoral Studies at the University of Latvia”. Authors are thankful to Prof. Indrikis Muižnieks for discussion and advices and to Prof. Isaak Rashal for recommendations and for providing fruit fly lines.

\section{REFERENCES}

Affleck, J.G., Walker, V.K. (2008). A role for Drosophila in understanding drug-induced cytotoxicity and teratogenesis. Cytotechnology, 57, 1-9.

Anonīms (2010). Latvijas Republikas Ministru Kabineta Noteikumi Nr. 1131 [Republic of Latvia Cabinet Regulation No. 1131]. Rīga 2010. gada 21. decembris. http://www.likumi.lv/doc.php?id=223481 (in Latvian)

Bahadorani, S., Hilliker, A.J. (2008). Cocoa confers life span extension in Drosohila melanogaster. Nutr. Res., 28, 377-382.

Chang, S-T., Buswell, J.A., Miles, P.G. (1999). Genetics and Breeding of Edible Mushrooms. Netherlands: Gordon and Breach Science Publishers. $324 \mathrm{pp}$

Chihara, G., Hamuro, J., Maeda, Y.Y., Arai, Y., Fukuoka, F. (1970). Fractionation and purification of the polysaccharides with marked antitumor activity, especially lentinan, from Lentinus edodes (Berk.) Sing. (an edible mushroom). Cancer Res., 30, 2776-2781.

Cozens, D.D., Huges, E.W., Clark, R., Offer, J.M. (1981). The effect of lentinan on the in utero embryonic and foetal development of rat and postnatal development of the $\mathrm{F}_{1}$ offspring. Toxicol. Lett., 9, 71-76.

Cozens, D.D., Masters, R.E., Clark, R., Offer, J.M. (1981). The effect of lentinan on fertility and general reproductive performance of the rat. Toxicol. Lett., 9, 55-64.

Cozens, D.D., Masters, R.E., Clark, R. (1981 The effect of lentinan on pregnancy of the New Zealand white rabbit. Toxicol. Lett., 9, 65-69.

Demerc, M., Kaufman B.P. (1996). Drosophila Guide. Carnegie Institution of Washington, Washington. $46 \mathrm{pp}$.

Flynn, V.T. (1991 Is the shiitake an aphrodisiac and cause of longevity? In: Science and Cultivation of Edible Fungi (pp. 345-361). Maher, M. J. (ed.). RotterdamL Balkema.

Goldstein, S.H., Babich, H. (1989). Differential effects of arsenite and arsenate to Drosophila melanogaster in a combined adult/developmental toxicity assay. Bull. Environ. Contam. Toxicol., 42, 276-282.

Grotewiel, M.S., Martin I., Bhandari, P., Cook-Wiens, E. (2005). Functional senescence in Drosophila melanogaster. Ageing Res. Rev., 4, 372-397.

Haag, E. S., Doty, A. V. (2005) Sex determination across evolution: Connecting the dots. PLoS Biology, 3(1), e21.

Helfand, S.L., Rogina, B. (2003). Genetics of aging in the fruit fly, Drosophila melanogaster. Annu. Rev. Genet., 37, 329-348.

Hobbs, C.R. (2000). Medicinal value of Lentinus edodes (Berk.) Sing. (Agaricomycetideae). A literature review. Int. J. Med. Mushrooms., 2, 287-302.
Jafari, M., Felgner, J.S., Bussel, I.I., Hutchili, T., Khodayari, B., Rose, M.R. Vince-Cruz, C., Mueller, D. (2007). Rhodiola: A promising anti-aging chinese herb. Rejuv. Res., 10(4), 587-602.

Jafari, M., Zarban, A., Pham, S., Wang, T. (2008). Rosa damascena decreased mortality in adult drosophila. J. Med. Food., 1, 9-13.

Lemaitre, B., Hoffmann, J. (2007). The host defense of Drosophila melanogaster. Ann. Rev. Immunol., 25, 697-743.

Li, H.Y., Wang, X.M., Tan, J.Q., Chen, H.S. (1993). Effects of Coriolus versicolor polysaccharides on productivity and longevity in Drosophila melanogaster. Acta Pharm. Sinic., 14 Suppl, 44-47 (in Chinese).

Lee, H.H., Lee, J.S., Cho, J.Y., Kim, Y.E., Hong, E.K. (2009). Structural characteristics of immunostimulating polysaccharides from Lentinus edodes. J. Microbiol. Biotechn., 19(5), 455-461.

Lee, H.H., Lee, J.S., Cho, J.Y., Kim, Y.E., Hong, E.K. (2009). Study on immunostimulating activity of macrophage treated with purified polysaccharides from liquid liquid culture and fruiting body of Lentinula edodes. $J$. Microbiol. Biotechn., 19(6), 566-572.

Lutton, B., Callard, I. (2006). Evolution of reproductive - immune interactions. Integr. Comp. Biol., 46(6), 1060-1071.

MacBean, L.T., Parson, D.A. (1967). Directional selection for duration of copulation in Drosophila melanogaster. Genetics, 56, 233-239.

Matjuskova, N., Zorenko, T., Muiznieks, I. (2001). The effects of mushroom shiitake on ontogenesis and reproduction of the social vole Microtus socialis. Int. J. Med. Mushrooms, 3, 180.

Matova, N., Cooley, L. (2001). Comparative aspects of animal oogenesis. Review. Dev. Biol., 231(2), 291-320.

Miles, P.G., Chang, S-T. (1997). Mushroom Biology. Concise Basics and Current Developments. World Scientific, Singapore. 194 pp.

Mizuno, T. (1995). Shiitake, Lentinus edodes: Functional properties for medicinal and food purposes. Food Rev. Int., 11(1), 111-128.

Novak, M., Vetvicka, V. (2009). Glucans as biological response modifiers. Endocr. Metab. Immune Disord.: Drug Targets, 9, 67-75.

Pendleton, R.G., Rasheed, A., Hillman, R. (2000). Effects of adrenergic agents on locomotory behavior and reproductive development in Drosophila. Drug Develop. Res., 50, 142-146.

Singh, S.R., Singh, B.N. (2000). Male remating in D. ananassae evidence for interstrain variation in remating time and shorter duration of copulation during second mating. Zool. Sci., 17, 389-393.

Smith, J.E., Rowan, N.J., Sullivan, R. (2002). Medicinal mushrooms: A rapidly developing area of biotechnology for cancer therapy and other bioactivities. Biotechnol. Lett., 24, 1839-1845.

Stamets, P. (2002). Novel antimicrobials from mushrooms. HerbalGram, 54, 28-33.

Taira, K., Myashita, Y., Okamoto, K., Arimoto, S., Takahashi, E., Negishi, T. (2005). Novel antimutagenic factors derived from the edible mushroom Agrocybe cylindracea. Mutat. Res., 586, 115-123.

Tantawy, A.O., El-Helw, M.R. (1970). Studies on natural populations of Drosophila. IX. Some fitness components and their heritabilities in natural and mutant populations of Drosophila melanogaster. Genetics, 64, 79-91.

Tickoo, S., Russell, S. (2002). Drosophila as a model system for drug discovery and pathway screening. Curr. Opin. Pharmacol., 2, 555-560.

Vetvicka, V., Sima, P. (2004). $\beta$-Glucans in invertebrates. Invertebr. Surviv. $J .$, 1, 60-65.

Wasser, S.P., Weis, A.L. (1999). Medicinal properties of substances occurring in higher basidiomycetes mushrooms: Current perspectives. Review. Int. J. Med. Mushrooms, 1, 31-62.

Yap, A.-T, Ng, M.- L. (2005). The medicinal benefits of lentinan ( $\beta-1$, 3-D glucan) from Lentinus edodes (Berk.) Singer (Shiitake mushroom) trough oral administration. Int. J. Med. Mushrooms, 7, 175-191.

Zhang, M., Cui, S. W., Cheung, P. C. K., Wang, Q. (2007) Antitumor polysaccharides from mushrooms: A review on their isolation process, struc- 
tural charecteristics and antitumor activity. Review. Trends Food Sci. Tech., 18, 4-19.

Zhang, Y. Q., Matthies, H. J. G., Mancuso, J., Andrews, H. K., Woodrruff III, E., Friedman, D., Broadie, K. (2004) The Drosophila fragile X-relited generegulates axoneme differentiation during spermatogenesis. Dev. Biol., 270, 290-307.

Zhao, T., Zhang, Q., Qi, H., Liu, X., Li, Z. (2008) Extension of life and improvement of vitality of Drosophila melanogaster by long-term supplementation with different molecular weight polysaccharides from Porphyra haitensis. Pharmacol. Res., 57, 67-72.
Zorenko, T., Matjuskova, N., Muiznieks, I. (2003) The effects of mushroom shiitake on ontogenesis and reproduction of the social vole Microtus socialis (Rodentia, Cricetida). Balt. J. Lab. Anim. Sci., 13, 69-77.

Матюшкова, Н., Свилпе, Э., Муйжниекс, И. (2010) Влияние экстракта гриба шиитаке на продолжительность жизни и устойчивость к тепловому шоку Drosophila melanogaster [Influence of shiitake mushroom extract on the life span and heat shock resistance of Drosophila melanogaster]. Материалы докладов Международной конференции Генетика продолжительности жизни и старения. Коми научный центр УрО РАН, Сыктывкар, с. 55-60 (in Russian).

Received 12 May 2010

\section{ŠITAKĒ SĒNES Lentinula edodes IETEKME UZ Drosophila melanogaster REPRODUKTIVITĀTI}

Šitakē sēne Lentinula edodes ir plaši kultivēta ēdamā bazidiomicēte ar augstu uzturvērtību un plašu bioloǵiskās aktivitātes spektru, kas arvien plašāk tiek lietota kā pārtikas piedeva. Šajā darbā iegūti dati par L. edodes ekstrakta iedarbību uz modeḷobjekta augḷu mušas D. melanogaster vairošanās funkciju un attīstību. Šitakē karsta ūdens ekstrakts, standartizēts pēc polisaharīdu satura, tika izmantots kā barības piedeva, audzējot mušas banānu barotnēs. Lietojot kā barības piedevu ekstraktu ar polisaharīdu koncentrācijām $0.030 \%$ un $0.015 \%$, novēroja statistiski būtisku kūniṇu un mušu skaita palielināšanos, kā arī pozitīvu ietekmi uz kūniṇu dzīvotspēju. Drozofilu tēviṇiem, kas šitakē ekstrakta piedevu saņēma septiņas dienas, statistiski būtiski samazinājās kopulācijas latentais periods, bet pēc 30 dienu ilgstošas lietošanas statistiski būtiski palielinājās sakopulējošo mušu skaits. Mātītēm pēc septinām dienām samazinājās kopulācijas latentais periods un palielinājās sakopulējušo mušu skaits. Pēc 30 dienu barošanās perioda mātītēm nenovēroja pārošanās spējas un auglības izmaiņas. Turpmākajos pētījumos plānots noteikt bioloǵiski aktīvos savienojumus šitakē sēnes karsta ūdens ekstrakta frakcijās un raksturot to ietekmi uz vairošanās funkciju. 